\title{
Broadening Horizons through Distance Learning: New Challenges for Education in Brazil and Some Other Geographical Areas
}

\author{
Dilvani Oliveira Santos ${ }^{1}$, Janilson Pereira Torres Junior ${ }^{2}$, Clara Maria Santos de Lacerda ${ }^{3}$ \\ ${ }^{1}$ Department of Molecular and Cell Biology (Institute of Biology), Laboratory of Bio-Pathogens and Cell Activation \& Educational \\ Process-Labiopac \& ProEduc, University Federal Fluminense (UFF), Niterói, Brazil \\ ${ }^{2}$ Cultura Inglesa Idiomas, Rio de Janeiro, Brazil \\ ${ }^{3}$ Pontifical Catholic University of Rio de Janeiro (PUC-RIO), Rio de Janeiro, Brazil \\ Email: ^profa.dilvani.uff@gmail.com, ^santosdilvani@gmail.com, janilsontorresjunior@gmail.com, claradelacerda@gmail.com
}

How to cite this paper: Santos, D. O., Torres Junior, J. P., \& de Lacerda, C. M. S. (2019). Broadening Horizons through Distance Learning: New Challenges for Education in Brazil and Some Other Geographical Areas. Creative Education, 10, 156-162.

https://doi.org/10.4236/ce.2019.101012

Received: December 11, 2018

Accepted: January 20, 2019

Published: January 23, 2019

Copyright $\odot 2019$ by author(s) and Scientific Research Publishing Inc. This work is licensed under the Creative Commons Attribution International License (CC BY 4.0).

http://creativecommons.org/licenses/by/4.0/

\begin{abstract}
This article presents a brief history of distance education since its inception until present days, highlighting the correlations between that learning method and technological developments in the field of Education throughout the years. Furthermore, it aims at stressing that distance learning has always been a relevant subject in the field of education and is gaining ground all around the world once it is at the forefront of educational technology. Distance learning may enable learners to have widespread access to knowledge that they would not otherwise and, in this context, may keep alive the hope that teachers, students and educational public policies might converge so as to shape a promising future, especially in developing countries such as Brazil.
\end{abstract}

\section{Keywords}

Distance Learning, Cultural and Historical Issues of Distance Learning, Teaching and Learning Processes, Education in Brazil

\section{A Brief History of Distance Education}

Although the terms distance learning and distance education have been ubiquitous when discussing technology education in the last few years, the concept of asynchronous learning has been around for longer. Distance education begins as "correspondence education", which is the earliest version of distance education from the mid-nineteenth century in Europe (Britain, France, Germany) and the United States. In the latter, during the nineteenth century, there were also 
opportunities for higher education beyond the boundaries of university campuses. In 1873, Anna Ticknow ran a magazine that featured educational opportunities for women of all social classes to study at home. Ticknow's volunteer effort in Boston would enable more than 10,000 students to have access to education over 24 years

(http://iml.jou.ufl.edu/projects/spring01/declair/history.html). Communication, teaching and learning were made possible through printed materials which were delivered by the post office. In 1915, researchers decided to study the effectiveness of correspondence education versus traditional education, which led to the creation of the National Association of University Extension (NUEA). NUEA established new guidelines at a national level for credit transfer, credit acceptance of correspondence courses, and quality standards for correspondence educators. In the late 1970s and early 1980s, cable and satellite television came into use and brought about new possibilities for content distribution. The advent of the Internet and digital applications in the 1990s, combined with the demographic change of the distance learning student profile, has added a new dimension to distance education. These new technologies have brought educational opportunities for students open to non-traditional methods and the possibility of economic prosperity to higher education institutions (Distance Learning History, http://iml.jou.ufl.edu/projects/Spring01/deClair/history.html). Still in the 1990s, the Canadian researcher Paul Ross defined Open Learning as: the removal of restrictions, exclusions and privileges, the accreditation of students' previous experience, flexibility in managing the time variable, substantial changes in the traditional relationships between professors and students (Ross, 1990). Some years later, in 2002, the United Nations Educational, Scientific and Cultural Organization (UNESCO) defined distance learning in the following way: "Open and Distance Learning represent approaches that focus on opening up access to education and provision of training, freeing students from the constraints of time and place, and offer flexible learning opportunities to individuals and groups of students" (UNESCO, 2002).

Distance learning initiatives have sprung up around the word, and some countries have embraced it more enthusiastically. In countries such as Sweden and Germany (Holmberg, 2001), and Canada, France and Belgium (UNESCO Institute for Statistics, 2009) the use of distance learning has also been met with success. Moreover, in places such as Africa, where higher education systems face many restrictions, Open and Distance Learning (ODL) have a huge potential (Karsenti \& Collin, 2012).

The emergence and development of information and communication technologies (ICTs) influenced the university culture. The last years have been marked by acute changes in teaching and learning procedures and methods. Students are no longer considered passive listeners. Conversely, they are supposed to proactively read, encode and decode whenever and wherever they are. In an online learning environment, adult learners need to take up much more 
responsibility for their learning and, as a result, they end up sharing their experience and knowledge with others (Schönwald, 2003; Tatkovic, Ruzic, \& Tatkovic, 2006; Dela Pena-Bandalaria, 2007; Carneiro, 2007; Sethy, 2008; Martins, 2008; Wheeler, 2010; eLearn Center, 2018).

\section{New Technologies in the Teaching and Learning Processes}

Many new technologies are interactive (Greenfield \& Cocking, 1996), and that fact makes the creation of environments in which students can build, learn and improve their understanding easier, which is conducive to knowledge acquisition. Nowadays, the learning process is moving towards the cyberspace (especially with the widespread use of the Internet and educational software and tools) that can help both students and teachers develop the skills needed for a prosperous present and future. New technologies offer opportunities to create new learning environments both on their own and together with traditional technologies such as books, blackboards, radio and television programs (eLearn Center, 2018).

When teachers learn how to use a new piece technology in their classrooms, they can innovate the learning process for students. At the same time, the teachers themselves have new insights into the learning process by watching their students work. Additionally, the role transference from teacher to student occurs in an authentic way during the use of computers in classrooms. Some students find it easy to interact with a certain new technology or software, spending a reasonable amount time on it, therefore mastering it before anyone else in the group, including their teachers. Sometimes teachers and students do not have any prior knowledge of the tool they are using, and then knowledge is built and shared in a collaborative manner, leading to memorable and remarkable interactions (eLearn Center, 2018).

Schools and Universities are supposed to play a larger role than just knowledge transmission. It is hard to argue against the idea that these institutions should be fostering the use of new technologies in order to allow their students to have a fair chance in the labor market competition. Therefore, the use of new technologies is indispensable in the daily life of the educational universe.

That said, the greatest challenge for teachers is not the amount of information, learning issues, or even identify the potential of modern technologies for education, but how to harness these technologies in the teaching and learning processes. Therefore, there are difficulties related to training those who will use them and to which pedagogical situations they are suitable for, as well as to the high costs of implementing them and their upkeep. It is crucial that we bear in mind that they represent large-scale investment which are not always readily available for educational purposes. Another important issue is the choice of content and, especially, appropriate methodologies to favor learning processes which can lead to the improvement of educational indexes. Currently, teacher's 
initial formation is far from able to equip them to make meaningful choices when it comes to establishing sound correlations between teaching methods and procedures, on one hand, and emergent technologies, on the other.

Nevertheless, there are currently countless successful learning experiences making use of new technologies in different areas of knowledge that have been reported and proven. Unfortunately, such experiences are yet to become widespread in Brazil, because of both cultural and historical reasons, and have not been fully accepted by teachers, students and public policies makers. It is worth considering that we often encounter prejudice when it comes to learning through digital media, exacerbated by the discontinuation of official policies in the field of education in Brazil, especially in relation to distance education.

One of the main benefits of distance education is that it is a way of learning with flexible schedules, which can be adjusted to meet each student's needs and demands. They have access to the classes and content taught in a given course often through a platform called virtual learning environment (VLE). This platform is usually equipped with all of the features necessary for creating an online classroom, allowing access to the content to be studied, projects, exercises and tests, as well as virtual contact, both synchronous and asynchronous, with teachers and tutors.

In a VLE, doubts are usually cleared within a set time limit. Moreover, students can do the activities whenever it is suitable for them, be it at home or even on their mobiles, as long as they have Internet access. Conversely, although it may seem simpler than face-to-face education, it takes a lot of self-discipline to be able to cope with the course demands properly. A lack of focus might cause students to become overwhelmed by the backlog of assignments and activities, which could, in turn, lead students to lose their motivation. Distance learning courses are usually organized into modules in which the content is presented gradually. The number of modules depends on the term and the course itself, but the dynamic remains the same. At the end of each module or lesson, students might be asked to sit tests as if they were in a traditional classroom. Follow-up exercises and supplemental materials are also available to help them with their studies, and they may represent optional or mandatory steps of the course.

On the whole, we believe distance learning is far from being a future perspective for education in Brazil, since our reality differs from the one in developed countries (Zeichner, 2008). Furthermore, we still have to overcome some critical, basic issues, such as the lack of available resources for acquisition and maintenance of essential equipment for the implementation of robust distance education platforms; the lack of public policies aimed at fostering the use of distance education in all spheres; the lack of a culture which encourages autonomy-a vital quality when taking distance learning courses due to their characteristics; and, finally, the lack of professionals who able to devise and implement distance education courses which are effective in enabling students to apply the knowledge acquired in such courses, resulting in a waste of time for the individual 


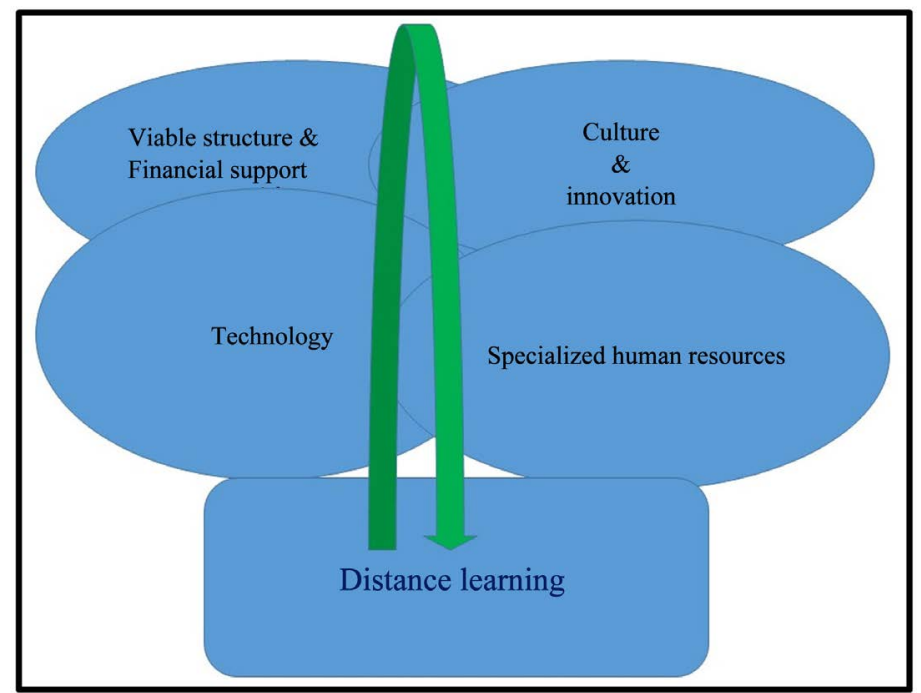

Figure 1. Relevant issues to consider when implementing distance learning.

and of the public funds dedicated to this purpose. Figure 1 illustrates the ideal environment in which distance learning can be promoted successfully: a combination of structure and financial support, applied technology, specialized human resources, and cultural aspects of the target geographical area.

These are the necessary ingredients in order to successfully implement distance learning platforms. They highlight the challenges that need to be tackled in developing countries, such as Brazil (Bielschowsky, 2018). Distance learning in Brazil could represent an impressive achievement for the country, since this system can enable people who work or live in far-flung places, or even those who have mobility impairments, to have unhindered access to higher education courses. In addition, the need to develop new methods and procedures to be used in distance learning could foster educational advances, which might also benefit face-to-face education. On the other hand, when comparing test results from both types of education (based on students enrolled in 2015 and 2016), the performance of distance learning students is worrisome, suggesting that the Brazilian educational system as a whole needs to hone its criteria when regulating and supervising distance learning institutions (Bielschowsky, 2018).

\section{Conclusion}

As we see it, in a somewhat optimistic view, the perspective for distance education being the future of education in Brazil depends on several changes, mainly cultural and political ones, only possible in the long run and with huge efforts from students, educators, and the public power.

\section{Acknowledgements}

We would like to thank the Universidade Federal Fluminense (UFF), Coordenação de Aperfeiçoamento de Pessoal de Nível Superior (CAPES), Programa de Pós-Graduação em Microbiologia e Parasitologia Aplicadas (UFF), Programa de 
Pós-Graduação em Ciências e Biotecnologia (UFF), Cultura Inglesa Idiomas (Rio de Janeiro, Brazil) and Pontifícia Universidade Católica do Rio de Janeiro (PUC-RJ) for the constant stimulus to work in the educational area.

\section{Conflicts of Interest}

The authors declare no conflicts of interest regarding the publication of this paper.

\section{References}

Bielschowsky, C. E. (2018). Qualidade na educação superior a distância no Brasil: onde estamos, para onde vamos? Revista. EaD em Foco, 8, e709. https://doi.org/10.18264/eadf.v8i1.709

Carneiro, R. (2007). The Big Picture: Understanding Learning and Meta-Learning Challenges. European Journal of Education, 42, 151-172. https://doi.org/10.1111/j.1465-3435.2007.00303.x

Dela Pena-Bandalaria, M. (2007). Impact of ICTs on Open and Distance Learning in a Developing Country Setting: The Philippine Experience. International Review of Research in Open and Distance Learning, 8, 1-15.

Distance Learning History. (http://iml.jou.ufl.edu/projects/Spring01/deClair/history.html).

eLearn Center (2018). http://openaccess.uoc.edu/webapps/o2/bitstream/10609/75705/6/ELR_Report_2017.pd $\underline{\mathrm{f}}$

Greenfield, P. M., \& Cocking, R. R. (Eds.) (1996). Interacting with Video. Norwood, NJ: Ablex. (Expanded Version of Greenfield \& Cocking, 1994)

Holmberg, C. (2001). Towards a New Scenario for Distance Education in Sweden. Contribution to the 20th World Conference on Open Learning and Distance Education, Düsseldorf, Germany, 1-5 April 2001.

Karsenti, T., \& Collin, S. (2012). Using IT for Distance Learning: Benefits and Challenges for African Learners. Teachers \& Teaching, 20, 9-18. https://doi.org/10.28945/1652

Martins, O. B. (2008). Os caminhos da EAD no Brasil. Revista Diálogo Educacional, Curitiba, 8 , 357-371.

Ross, P. (1990). Open Learning and Open Management: Leadership and Integrity in Distance Education. London: Kogan Page.

Schönwald, I. (2003). Sustainable Implementation of E-Learning as a Change Process at Universities. St. Gallen, Switzerland: Swiss Centre for Innovations in Learning.

Sethy, S. S. (2008). Distance Education in the Age of Globalization: An Overwhelming Desire towards Blended Learning. Turkish Online Journal of Distance Education, 9, Article 3. https://files.eric.ed.gov/fulltext/ED502078.pdf

Tatkovic, N., Ruzic, M., \& Tatkovic, S. (2006). Open Distant Learning: Pedagogical Terms of Reference and Dilemmas.

http://eric.ed.gov/ERICDocs/data/ericdocs2sql/content_storage_01/0000019b/80/27/f5/ 83.pdf

UNESCO (2002). Open and Distance Learning. Trends, Policy and Strategy Considerations. Paris: UNESCO.

UNESCO Institute for Statistics (2009). Global Education Digest: Comparing Education 
Statistics across the World. Montréal, QC: UNESCO-UIS.

http://www.uis.unesco.org/Library/Documents/ged09-en.pdf

Wheeler, S. (2010). Open Content, Open Learning 2.0: Using Wikis and Blogs in Higher Education. In U. Ehlers, \& D. Schneckenberg (Eds.), Changing Cultures in Higher Education: Moving Ahead to Future Learning. New York: Springer International. https://doi.org/10.1007/978-3-642-03582-1_9

Zeichner, K. (2008). A Critical Analysis of Reflection as a Goal for Teacher Education. Education and Society, 29, 535-554. https://doi.org/10.1590/S0101-73302008000200012 